\title{
PERAN NILAI EMOSIONAL DALAM MEMEDIASI PENGARUH PERSEPSI KUALITAS TERHADAP NIAT BELI
}

\author{
Putu Angga Agusta Bimartha ${ }^{1}$ \\ Ni Made Asti Aksari \\ ${ }^{1,2}$ Fakultas Ekonomi dan Bisnis Universitas Udayana (Unud), Bali, Indonesia \\ E-mail: anggaagustha@gmail.com
}

\begin{abstract}
ABSTRAK
Penelitian ini bertujuan untuk menjelaskan pengaruhpersepsi kualitas dan nilai emosional terhadap niat beli Sepatu Olahraga Lari Nike, dan bagaimana peran nilai emosional dalam memediasi pengaruh persepsi kualitas terhadap niat beli Sepatu Olahraga Lari Nike. Penelitian ini dilakukan pada penduduk yang berdomisili di Kota Denpasar. Populasi dalam penelitian ini bersifat infinite (tidak terbatas). Jumlah sampel yang digunakan sebanyak 100 responden, penentuan sampel menggunakan metode non probability sampling dengan teknik purposive sampling. Metode pengumpulan data yang digunakan adalah survey dengan menggunakan kuesioner sebagai instrumen penelitian, data yang terkumpul dianalisis menggunakan teknik analisis jalur (path analysis). Hasil penelitian menunjukkan bahwa persepsi kualitas memiliki pengaruh positif dan signifikan terhadap nilai emosional, dan persepsi kualitas juga secara positif dan signifikan berpengaruh terhadap niat beli, sedangkan nilai emosional memiliki pengaruh positif dan signifikan terhadap niat beli dan mampu memediasi hubungan persepsi kualitas terhadap niat beli secara tidak langsung.
\end{abstract}

Kata kunci: persepsi kualitas, nilai emsional, niat beli

\begin{abstract}
This study aims to explain the influence of perceived quality and emotional value towards purchase intention of Nike Running Shoes, and the role of emotional value in mediating the influence of perceived quality on the purchase intention of Nike Running Shoes. This research was conducted on people living in Denpasar City. The population of this study is infinite. The number of samples used was 100 respondents and, was determined using nonprobability sampling method with purposive sampling technique. The data was collected throughsurvey using questionnaires and analyzed using path analysis techniques. The results show that quality perception have a positive and significant effect on emotional value, and perceived quality also have a positive and significant effect on purchase intention, while emotional value has a positive and significant influence on purchase intention and is able to mediate the relationship of perceived quality indirectly to purchase intention.
\end{abstract}

Keywords: perceived quality, emotional value, purchase intention 


\section{PENDAHULUAN}

Pentingnya memahami kepuasan dan keinginan konsumen mulai menjadi perhatian dari berbagai macam industri salah satunya industri olahraga. Industri olahraga adalah kegiatan bisnis bidang olahraga dalam bentuk produk barang dan/atau jasa (Undang-Undang Republik Indonesia Tentang Sistem Keolahragaan Nasional, 2005:4). Industri sepatu olahraga merupakan salah satu industri yang memiliki persaingan yang ketat di Indonesia.Persaingan kompetitif ditunjukkan dengan berbagai pilihan sepatu yang tersedia di pasar. Beberapa perusahaan besar yang memproduksi produk sepatu olahraga seperti Adidas, Nike, dan Puma mengalami persaingan di industri ini (Laluyan et al., 2017). Persaingan di industri sepatu olahraga di Indonesia juga dikuti oleh produsen lokal yang dapat bersaing secara kompetitif dengan perusahaan internasional seperti Specs, League, dan Piero.

Salah satu perusahaan besar yang memproduksi sepatu olahraga dalam bidang olahraga lari adalah Nike. Pada awalnya Nike, dikenal sebagai BRS (Blue Ribbon Sports), pendiri dari perusahaan ini adalah atlet trek Philip Knight dan pelatihnya Bill Bowerman dari Universitas Oregon (University of Oregon) yang didirikan pada tahun 1964.Pada perjalanannya sekarang Nike tidak hanya menjual sepatu, mereka mulai menjual pakaian dan peralatan olahraga dalam berbagai jenis olahraga (Zuhra, 2017).

Nike merupakan salah satu merek yang populer pada jenis sepatu olahraga lari. Pada akhir tahun 2017 Google merilis sepatu olahraga yang paling banyak dicari di situs Google, hasilnya menyebutkan bahwa produk sepatu olahraga Nike 
adalah sepatu yang paling populer dicari dalam situs pencarian Google, yaitu sepatu olahraga lari berjenis Nike Air Max 97 (Alissa, 2017). Terlihat bahwa produk sepatu olahraga lari Nike masih merupakan produk yang paling dicari oleh masyarakat dunia karena berada pada posisi pencarian paling tinggi pada tahun 2017 pada situs pencarian Google. Nike pun juga memiliki eksistensi di Indonesia, Nike telah mensponsori Timnas Sepak bola Indonesia sejak Tahun 2006 sampai saat ini, dan Nike telah mempersiapkan baju olahraga terbaru bagi Timnas Indonesia dalam ajang Asian Games 2018 (Dewi, 2017).

Nike merupakan salah satu merek yang memiliki reputasi yang baik di Indonesia. Menurut hasil survei yang dilakukan oleh majalah marketing yang bekerjasama dengan Frontier Consulting Group pada tahun 2017, Nike berhasil menduduki peringkat sebagai Top Brand dalam kategori sepatu olahraga lari. Top Brand adalah penghargaan yang diberikan kepada merek-merek terbaik pilihan konsumen (Top Brand, 2017). Hasil survei dapat dilihat pada Tabel 1.

Tabel 1.

Peringkat Top Brand Index Tahun 2016-2017

\begin{tabular}{ccccccc}
\hline & \multicolumn{2}{c}{ Tahun 2016 } & \multicolumn{3}{c}{ Tahun 2017 } \\
No & Merek & TBI (\%) & Ket. & Merek & TBI (\%) & Ket. \\
\hline 1 & Adidas & 37.4 & Top & Adidas & 38.2 & Top \\
2 & Nike & 29.6 & Top & Nike & 32.2 & Top \\
3 & Reebok & 3.7 & & Converse & 3.6 & \\
4 & Bata & 3.6 & & Eagle & 3.3 & \\
5 & Eagle & 3 & & Reebok & 3.3 & \\
\hline Sumber:
\end{tabular}

Sumber: Top Brand Award, 2017

Tabel 1 menunjukkan bahwa nilai TBI (Top Brand Index) yang didapatkan Nike termasuk dalam kategori Top Brand. TBI didapatkan melalui hasil survei dengan melihat tiga parameter yakni top of mind share, top of market 
share dan top of commitment share. Merek yang terpilih menjadi Top Brand adalah merek yang memperoleh TBI minimum sebesar $10.0 \%$ dan menurut hasil survei berada dalam posisi top three (Top Brand, 2017). Selama dua tahun berturut-turut yaitu tahun 2016 hingga tahun 2017 Nike selalu berada pada posisi Top Brand, hal ini menunjukan bahwa Nike adalah salah satu pilihan untuk memenuhi keinginan dan kepuasan konsumen pada sepatu olahraga lari. Kepuasan konsumen merupakan bagian dari keputusan konsumen sehingga salah satu hal sebelum terjadinya keputusan konsumen adalah niat untuk membeli (Simamora, 2008). Niat beli adalah evaluasi dan sikap konsumen terhadap produk dengan melihat faktor eksternal sehingga berdampak pada kesediaan konsumen untuk membeli produk (Wen dan Li, 2013). Niat beli dapat digunakan untuk menganalisis perilaku konsumen, sebelum melakukan pembelian konsumen akan mencari informasi tentang suatu produk, kemudian konsumen akan melakukan penelitian terhadap produk berdasarkan informasi yang mereka miliki, selanjutnya konsumen akan melakukan perbandingan produk dan melakukan evaluasi serta membuat suatu keputusan pembelian (Ismayanti dan Santika, 2017).

Salah satu hal menentukan dari niat pembelian adalah adanya persepsi kualitas.Yamin (2013) mengatakan bahwa persepsi kualitas dapat didefinisikan sebagai persepsi pelanggan terhadap kualitas dan keunggulan produk atau jasa yang berkaitan dengan maksud yang diharapkan oleh pelanggan. Kualitas yang dirasakan adalah persepsi pelanggan terhadap kualitas serta keunggulan suatu produk atau layanan jasa (Xu et al., 2015). Persepsi kualitas menurut Tjiptono (2012:84) adalah penilaian konsumen terhadap keunggulan keseluruhan suatu 
produk atau jasa layanan ditinjau dari fungsinya secara relatif dengan produk produk lain. Persepsi terhadap kualitas keseluruhan dari suatu produk atau jasa dapat menentukan nilai dari produk atau jasa tersebut dan berpengaruh secara langsung kepada keputusan pembelian konsumen dan loyalitas mereka terhadap merek (Durianto dkk., 2011: 101).

Nilai dari produk atau jasa dapat berpengaruh secara langsung dalam memilih produk. Konsumen akan cenderung memilih merek yang sudah mereka kenal dengan baik dan memberikan perasaan positif kepada dirinya, baik nilai secara fungsional maupun secara emosional (Saidani dkk., 2017). Nilai emosional merupakan salah satu dimensi nilai yang dikatakan sangat penting (Filz et al., 2016). Hawkins dan Mothersbough (2010:115) menyatakan didalam pemasaran, nilai emosi adalah salah satu nilai yang digunakan untuk menyususn strategi pemasaran. strategi pemasaran yang dapat digunakan adalah dengan menawarkan produk yang mempunyai nilai positif. Apabila konsumen mengalami perasaaan positif (positive feeling) pada saat membeli atau mengggunakan suatu merek, maka merek tersebut memberikan nilai emosional (Simamora, 2002:15).

Penelitian ini dilakukan berdasarkan beberapa temuan dari penelitian sebelumnya tentang pengaruh persepsi kualitas, nilai emosional dan niat beli dengan hasil yang berbeda-beda. Pada penelitian yang dilakukan oleh Lee et al. (2008) menyatakan bahwa persepsi kualitas berpanguruh negatif terhadap niat beli, hasil yang sama juga dinyatakan dalam penelitian yang dilakukan oleh Kumar dan Kim (2008) yang menyatakan bahwa persepsi kualitas berpanguruh negatif terhadap niat beli. Pendapat yang berbeda diungkapkan dalam penelitian 
yang dilakukan oleh Shah et al. (2012) yang menyatakan bahwa persepsi kualitas dan nilai emosional berpangaruh positif terhadap niat beli. Hal ini sejalan dengan penelitian yang dilakukan oleh Nadya dan Sihombing (2012) yang menyatakan bahwa persepsi kualitas dan nilai emosional berpangaruh positif terhadap niat beli.

Persepsi kualitas menurut Tjiptono (2012:84) adalah penilaian konsumen terhadap keunggulan keseluruhan suatu produk atau jasa layanan ditinjau dari fungsinya secara relatif dengan produk - produk lain. Schiffman et al. (2010:195) menyatakan bahwa Perceived quality konsumen tergantung dari berbagai informasi yang berhubungan dengan produk itu sendiri. Menururt Xu et al. (2015) kualitas yang dirasakan adalah persepsi pelanggan terhadap kualitas serta keunggulan suatu produk atau layanan jasa. Persepsi terhadap kualitas produk mengakibatkan seorang memiliki niat atau tidak dalam mengkonsumsi suatu produk karena persepsi kualitas produk merupakan salah satu pertimbangan konsumen dalam menggunakan produk yang nantinya dapat memberikan manfaat yang diinginkan setiap konsumen (Kotler dan Keller, 2012:228).

Wijaya dkk. (2013) menyatakan bahwa persepsi kualitas meliputi segala sesuatu yang berkaitan dengan bagaiamana suatu merek dipersepsikan sehingga dengan diketahuinya persepsi pelanggan terhadap kualitas dari merek yang dimiliki maka perusahaan dapat menentukan langkah-langkah apa yang dapat diambil guna memperkuat persepsi pelanggan terhadap merek yang dimilki oleh perusahaan tersebut. Hertanto (2013) menyatakan bahwa persepsi terhadap kualitas keseluruhan dari suatu produk dapat menentukan nilai dari produk 
tersebut dan berpengaruh secara langsung kepada keputusan pembelian konsumen dan loyalitas mereka terhadap merek. Perceived quality merupakan persepsi konsumen yang dapat di ramalakan, jika perceived quality konsumen negatif maka produk tidak akan disukai dan tidak akan bertahan lama di pasar, sementara jika perceived quality positif maka produk akan disukai (Setyawan, 2010).

Komponen penyusun persepsi kualitas menurut (Lee et al., 2008) dan (Kotler dan Armstrong, 2012:283) yang membentuknya yaitu. 1) Kualitas Tinggi, produk memiliki mutu dan kualitas yang baik yang sesuai dengan spesifikasi yang telah ditentukan ataupun kesesuaiannya terhadap kebutuhan. 2) Ketahanan, adalah konsistensi kinerja suatu produk dari satu pembelian hingga pembelian berikutnya dan presentasi waktu yang dimiliki produk tersebut sesuai dengan nilai hidup ekonominya. 3) Memiliki reputasi yang baik, suatu produk telah memiliki kesan, perasaan, gambaran dari publik terhadap perusahaan yang baik. 4) Merek bergengsi, adalah merek atau brand yang memiliki nilai lebih dari kompetitornya sehingga membuat merek atau brand tersebut menjadi berebeda dan bernilai tinggi. 5) Andal, andal adalah konsistensi kinerja performa produk dari masa kemasa dan kemampuan yang dimiliki produk untuk befungsi sebagaimana mestinya.

Nilai emosional adalah perasaan yang disebabkan oleh pemenuhan kebutuhan melalui sebuah produk atau merek (Babin dan Haris, 2011:94). Sadat (2009:36) menyatakan bahwa nilai emosional adalah sentuhan emosional terhadap merek yang mereka tawarkan, meskipun untuk produk yang selama ini dipasarkan sebatas mengandalkan fungsinya. Melalui sentuhan emosional, para pemasar 
percaya bahwa hal yang ditawarkan akan memberikan perasaan tersendiri bagi pelanggannya. Nilai emosional berhubungan dengan perasaan, yaitu perasaan positif apabila konsumen mengalami perasaan positif pada saat membeli atau menggunakan suatu merek, maka merek itu memberikan nilai emosional (Simamora, 2002: 15). Nilai emosional yang didapatkan dari produk atau merek akan mempengaruhi niat beli konsumen. Nilai emosi yang didapatkan oleh dari produk atau merek akan mempengaruhi niat beli konsumen oleh karena itu di dalam pemasaran, nilai emosional adalah salah satu nilai yang digunakan untuk menyusun strategi pemasaran (Hawkins dan Mothersbough, 2010: 115).

Menurut Hawkins dan Mothersbaugh (2010) dan Shah et al. (2012) dimensi dari nilai emosional dan indikator yang membentuknya yaitu. 1) Kebanggaan: bangga, superior, layak. 2) Kasih sayang: penuh kasih, sayang, ramah 3) Ketenangan: tenang, tentram, nyaman, menenangkan. 4) Keinginan: berkeinginan, angan-angan, ketagihan, penuh harapan. 5) Sukacita: menikmati, senang, gembira, puas. 6) Kompeten: percaya diri, terkendali, kompeten.

Niat beli adalah evaluasi dan sikap konsumen terhadap produk dengan melihat faktor eksternal sehingga berdampak pada kesediaan konsumen untuk membeli produk (Wen dan $\mathrm{Li}, 2013$ ). Didalam proses niat beli, konsumen akan membentuk pilihan mereka diantara beberapa merek yang tergabung dalam perangkat pilihan, kemudian pada akhirnya melakukan suatu pembelian pada suatu alternative yang paling disukainya atau proses yang dilalui konsumen untuk membeli suatu barang atau jasa yang didasari oleh bermacam pertimbangan (Annafik dan Rahardjo, 2012). Niat beli dapat diartikan sebagai suatu sikap senang terhadap suatu objek 
yang membuat individu berusaha untuk mendapatkan objek tersebut dengan cara membayarnya dengan uang atau pengorbanan (Schiffman et al., 2010:79). Kotler dan Keller (2012:54) menyatakan bahwa purchase intention merupakan salah satu tahap yang ada di dalam decision-making-process pada consumer behaviour (perilaku konsumen) dan menjelaskan bahwa purchase intention (niat beli) adalah keinginan yang timbul untuk membeli setelah konsumen mengevaluasi produk pada beberapa merek lalu memilih satu merek yang paling diminati. Niat membeli merupakan keputusan yang mempelajari mengapa konsumen membeli suatu produk, pemasar akan mencari apa sebab-sebab seorang pelanggan untuk membeli pada suatu merek atau produk tertentu. Cara lain untuk memeriksa perilaku niat beli konsumen adalah untuk menilai kesediaan mereka untuk membayar (Barber et al., 2012). Meningkatnya niat membeli akan membawa dampak yang positif terhadap penjualan produk di pasar.

Dalam penelitian Lobo dan Chen (2012) serta Indrayani dan Nurcahya (2014) disebutkan beberapa indikator yang di gunakan untuk mengukur niat beli yaitu sebagi berikut: 1) Niat membeli dalam waktu tertentu, dalam hal ini yang dimaksud adalah keinginan seseorang untuk membeli produk dimasa yang akan datang. 2) Keinginan untuk mencoba, merupakan suatu keinginan yang timbul dalam diri seseorang yang mengakibatkan suatu reaksi untuk mencoba suatu produk. 3) Kesedian untuk membeli, merupakan kesanggupan atau kerelaan seseorang untuk membeli suatu produk.

Menurut Lee et al. (2008), nilai utilitarian (fungsional) dan nilai hedonik (emosi) pada suatu produk atau merek memiliki hubungan. Secara spesifik, 
semakin tinggi persepsi kualitas akan suatu merek, maka semakin tinggi nilai emosional pada merek tersebut. Berdasarkan penelitian yang dilakukan oleh Nadya dan Sihombing (2012) pada hubungan antara pengaruh normatif dan niat beli pada pakaian merek luar negeri menyatakan bahwa terdapat hubungan positif antara variabel persepsi kualitas dan nilai emosional di dukung. Shah et al. (2012) dalam penelitiannya pada niat beli mahasiswa di Universitas Pakistan terhadap pakaian merek luar negeri juga menyatakan bahwa persepsi kualitas berdampak signifikan terhadap nilai emosional Selain itu menurut Lee et al. (2008) yang melakukan penelitian mengenai faktor-faktor yang mempengaruhi niat beli mahasiswa Mexico pada pakian merek Amerika menyatakan bahwa persepsi kualitas memiliki hubungan yang positif dan signifikan terhadap nilai emosional. Berdasarkan dari hasil penelitian sebelumnya, maka pada penelitian ini dapat ditarik hipotesis sebagai berikut.

H1: Persepsi kualitas berpengaruh positif dan signifikan terhadap nilai emosional Menurut Kotler dan Keller (2012:228) persepsi terhadap kualitas produk mengakibatkan seorang memiliki niat atau tidak dalam mengkonsumsi suatu produk karena persepsi kualitas produk merupakan salah satu pertimbangan konsumen dalam menggunakan produk yang nantinya dapat memberikan manfaat yang diinginkan setiap konsumen. Levy dan Guterman (2012) menyatakan bahwa persepsi kualitas sangat penting dalam memprediksi niat beli merek, sehingga terdapat pengaruh positif signifikan pada persepsi kualitas terhadap niat beli. Selain itu Hendrayana dan Santika (2015) dalam penelitianya mengenai niat membeli secara online pada situs belanja online Zalora di Denpasar menunjukan 
bahwa variabel persepsi kualitas produk berpengaruh positif dan signifikan terhadap niat membeli secara online pada situs belanja online Zalora. Indrayani dan Nurcahya (2014) juga mengemukakan penelitianya mengenai niat beli produk handphone Samsung, menyatakan terdapat pengaruh positif dan signifikan antara variabel persepsi kualitas produk terhadap niat beli. Pendapat yang sama juga dikemukakan oleh Putri dan semuel (2016) serta Anggi dan Ellyawati (2015). Berdasarkan dari hasil penelitian sebelumnya, maka pada penelitian ini dapat ditarik hipotesis sebagai berikut.

$\mathrm{H}_{2}$ : Persepsi kualitas berpengaruh positif dan signifikan terhadap niat beli

Nilai emosional yang didapatkan dari produk atau merek akan mempengaruhi niat beli konsumen, oleh karena itu di dalam pemasaran, nilai emosional adalah salah satu nilai yang digunakan untuk menyusun strategi pemasaran (Hawkins dan Mothersbough, 2010:115). Menurut Saidani dkk. (2017) menyatakan dalam penelitianya mengenai produk Tas Consina ternyata terdapat pengaruh persepsi kualitas, brand image dan nilai emosional pada niat beli, dimana nilai emosional memiliki pengaruh positif terhadap niat beli. Berdasarkan penelitian yang telah dilakukan oleh Kashi (2013) mengenai perilaku pembelian konsumen antara brand luar negeri dan brand lokal terdapat bahwa variabel Nilai Emosional berpengaruh signifikan terhadap niat beli. Nadya dan Sihombing (2012) juga mengemukakan dalam penelitianya mengenai pengaruh normatif dan niat beli pakaian merek luar negeri bahwa terdapat hubungan positif antara nilai emosional dan niat beli di dukung.

$\mathrm{H}_{3}$ : Nilai emosional berpengaruh secara positif dan signifikan terhadap niat beli 
Berdasarkan penelitian yang dilakukan oleh Shah et al. (2012) mengenai niat beli mahasiswa di Universitas Pakistan terhadap pakaian merek luar negeri menemukan bahwa persepsi kualitas mempunyai pengaruh secara siginifikan terhadap niat membeli melalui adanya media nilai emosional. Pada penelitian yang dilakukan oleh Nadya dan Sihombing (2012) mengenai pengaruh normatif dan niat beli pakaian merek luar negeri menyatakan bahwa persepsi kualitas mempunyai pengaruh secara siginifikan terhadap niat membeli melalui adanya media nilai emosional. Hasil peneltitian yang ditemukan oleh Latter et al. (2010) pada penelitiannya mengenai mengenai peran konsumen membutuhkan keunikandan status konsumsi dimana peran nilai emosional dapat memediasi niat beli.

H4: Persepsi kualitas berpengaruh secara positif dan signifikan terhadap niat beli melalui nilai emosional

\section{METODE PENELITIAN}

Lokasi penelitian dilakukan di wilayah Kota Denpasar. Lokasi ini dipilih karena Kota Denpasar adalah ibu kota Provinsi Bali yang memiliki sektor pergerekan ekonomi yang tumbuh cepat dengan jumlah penduduk yang padat. Pada data Badan Pusat Statistik (BPS) Kota Denpasar disebutkan bahwa jumlah penduduk di kota Denpasar berjumlah 3.890.757 juta peduduk. Adapun PDRB Kota Denpasar atas dasar harga berlaku menurut pengeluaran dari tahun 2010 hingga dengan tahun 2016 selalu mengalami peningkatan (Badan Pusat Statistik, 2016). Objek di dalam penelitian ini adalah pengaruh persepsi kualitas (X) terhadap nilai emosional(Y1), pengaruh persepsi kualitas (X) terhadap niat beli 
(Y2), pengaruh nilai emosional (Y1) terhadap niat beli (Y2), pengaruh nilai mosional (Y1) memediasi persepsi kualitas (X) dan niat beli (Y2).

Seluruh variabel dan Indikator masing-masing variabel disajikan secara ringkas pada Tabel 2.

Tabel 2.

Operasional Variabel Penelitian

\begin{tabular}{|c|c|c|}
\hline Variabel & Indikator & Sumber \\
\hline $\begin{array}{c}\text { Persepsi } \\
\text { Kualitas (X) }\end{array}$ & $\begin{array}{ll}\text { 1. } & \text { Kualitas tinggi (X1.1) } \\
\text { 2. } & \text { Ketahanan (X1.2) } \\
\text { 3. } & \text { Reputasi yang baik (X1.3) } \\
\text { 4. } & \text { Merek bergengsi (X1.4) } \\
\text { 5. } & \text { Andal (X1.5) }\end{array}$ & $\begin{array}{l}\text { (Lee } \text { et al., 2008); (Kotler dan Armstrong, } \\
\text { 2012:283) }\end{array}$ \\
\hline $\begin{array}{c}\text { Nilai } \\
\text { Emosional } \\
\quad(\mathrm{Y} 1)\end{array}$ & $\begin{array}{ll}\text { 1. } & \text { Kebanggaan (Y1.1) } \\
\text { 2. } & \text { Kasih sayang (Y1.2) } \\
\text { 3. } & \text { Ketenangan (Y1.3) } \\
\text { 4. } & \text { Keinginan (Y1.4) } \\
\text { 5. } & \text { Sukacita (Y1.5) } \\
\text { 6. } & \text { Kompeten (Y1.6) }\end{array}$ & $\begin{array}{l}\text { (Hawkins dan Mothersbaugh, 2013); } \\
\text { (Shah } \text { et al., 2012) }\end{array}$ \\
\hline $\begin{array}{l}\text { Niat Beli } \\
\quad(Y 2)\end{array}$ & $\begin{array}{ll}\text { 1. Niat membeli dalam waktu } \\
\text { tertentu (Y2.1) } \\
\text { 2. Keinginan untuk mencoba } \\
\text { (Y2.2) } \\
\text { 3. Kesedian untuk membeli } \\
(Y 2.3)\end{array}$ & $\begin{array}{l}\text { (Lobo dan Chen , 2012); (Indrayani dan } \\
\text { Nurcahya, 2014) }\end{array}$ \\
\hline
\end{tabular}

Sumber: Data diolah, 2018

Populasi dalam penelitian ini adalah penduduk di wilayah Denpasar. Populasi dalam penelitian ini bersifat infinite (tidak terbatas). Sampel dalam penelitian ini adalah responden yang mengetahui informasi produk sepatu olahraga lari Nike. Metode penentuan sampel yang digunakan dalam penelitian ini adalah non probability sampling. Tehnik pengambilan sampel ditentukan dengan metode purposive sampling merupakan metode pemilihan sampel berdasarkan pertimbangan tertentu. 
Metode pengumpulan data yang digunakan dalam penelitian ini adalah survey atau angket. Instrumen penelitiannya adalah kuesioner. Kuesioner merupakan metode pengumpulan data yang dilakukan dengan cara memberikan seperangkat pertanyaan tertulis pada responden untuk dijawabnya (Sugiyono, 2017:142). Tipe pertanyaan pada kuesioner adalah pertanyaan tertutup, dimana responden diminta untuk membuat pilihan dari serangkaian alternatif pilihan jawaban yang terdapat di kuesioner. Alternatif jawaban yang terdapat dalam kuesioner merupakan pengembangan dari setiap item dalam variabel penelitian. Responden harus memberikan pendapatnya dengan cara memberi tanda tertentu pada jawaban yang dipilih. Pertanyaan yang diberikan menyangkut pada indikator masing-masing variabel yang digunakan dalam penelitian ini. Pertanyaan dalam kuesioner dibuat dengan menggunakan skala Likert.

Teknik analisis data yang digunakan dalam penelitian ini adalah teknik analisis jalur (path analysis). Teknik analisis jalur ini dapat didefinisikan sebagai perluasan dari analisis linier berganda dalam memperkirakan hubungan kausalitas antara yang telah ditetapkan berdasarkan teori. Analisis jalur digunakan untuk menentukan hubungan 3 variabel atau lebih dalam mengkorfimasi dan menolak hipotesis (Ghozali, 2011:249). Analisis jalur digunakan untuk menentukan pola hubungan antara tiga atau lebih dan tidak dapat digunakan untuk mengkonfirmasi atau menolak hipotesis. Riduwan dan Kuncoro (2011:2) menyatakan analisis jalur digunakan untuk menganalisis pola hubungan antar variabel dengan tujuan untuk mengetahui pengaruh langsung maupun tidak langsung seperangkat variabel 
bebas terhadap variabel terikat.Berdasarkan model penelitian maka diagram jalur dalam penelitian ini dapat disajikan sebagai berikut.

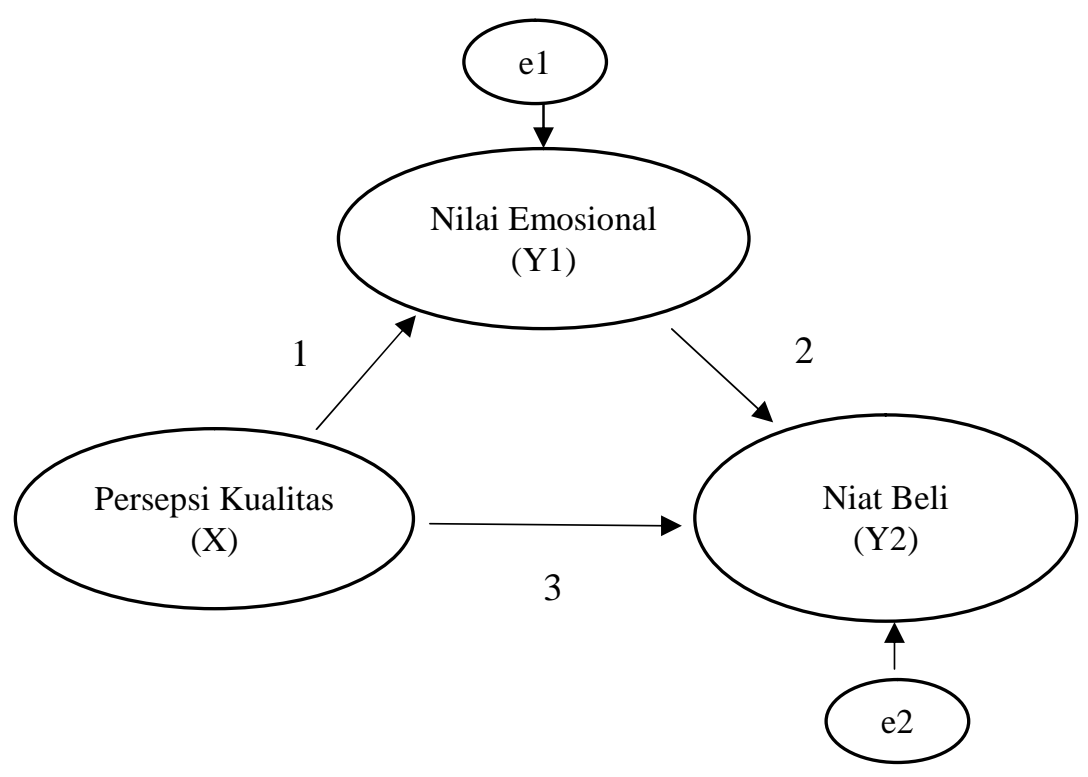

Gambar 1. Diagram Jalur

\section{HASIL PENELITIAN DAN PEMBAHASAN}

Responden dalam penelitian ini berjumlah 100 orang. Seluruh responden yang digunakan pada penelitian ini sudah dipastikan berdomisili di kota Denpasar, berpendidikan terakhir minimal SMA sederajat, mengetahui informasi produk sepatu olahraga lari Nikedan mempunyai niat beli pada sepatu olahraga Nike. Karakteristik responden disajikan pada Tabel 3.

Tabel 3.

Karakteristik Responden

\begin{tabular}{ccccc}
\hline No & Variabel & Klasifikasi & Jumlah & Persen \\
\hline 1 & Usia & $<20$ Tahun & 5 & $5 \%$ \\
& & $20-25$ Tahun & 92 & $92 \%$ \\
& & $>25$ Tahun & 3 & $3 \%$ \\
& & Jumlah & 100 & $100 \%$ \\
& Jenis Kelamin & Pria & 64 & $64 \%$
\end{tabular}




\begin{tabular}{cccc} 
& Wanita & 36 & $36 \%$ \\
& Jumlah & 100 & $100 \%$ \\
& SMA Sederajat & 42 & $42 \%$ \\
& Pendidikan Terakhir & 58 & $58 \%$ \\
& Jumlah & 100 & $100 \%$ \\
\hline
\end{tabular}

Sumber: Data diolah, 2018

Berdasarkan Tabel 3 dapat dilihat menurut pengelompokan usia, mayoritas responden berusia 20 - 25 tahun sebanyak 92\%, lalu responden berusia diatas 25 tahun sebanyak 3\% dan responden berusia dibawah 20 tahun sebanyak 5\%. Dilihat dari jenis kelamin responden, Pria yaitu sebanyak 64\% dan Wanita sebanyak 36\%. Dilihat pada tingkat pendidikan, SMA/Sederajat sebesar $42 \%$, Perguruan Tinggi 58\%.

Pengujian persamaan 1 dilakukan untuk melihat pengaruh persepsi kualitas terhadap nilai emosional yang dilakukan dengan menggunakan program SPSS. Berdasarkan hasil uji regresi dapat disajikan dalam Tabel 4 berikut:

Tabel 4.

Hasil Uji Regresi Pengaruh Persepsi Kualitas terhadap Nilai Emosional Model Unstandardized Coefficients Standardized Sig. Coefficients

\begin{tabular}{lllllll}
\multicolumn{9}{c}{ B } & Std. Error & Beta \\
\hline 1 & (Constant) & 1.766 & 2.302 & & .767 & .445 \\
& Persepsi Kualitas & .920 & .106 & .698 & 9.636 & .000 \\
\hline Sumber: & Data diolah, 2018 & &
\end{tabular}

Persamaan Struktural 1

$$
\begin{aligned}
& \mathrm{Y}_{1}=\beta_{1} \mathrm{X}+\varepsilon_{1} \ldots \\
& \mathrm{Y}_{1}=0,698 \mathrm{X}+\varepsilon_{1}
\end{aligned}
$$


Tabel 4 Menunjukkan hasil uji regresi pengaruh persepsi kualitas terhadap nilai emosional dengan nilai Sig. 0,000 $<0,05$ menunjukkan bahwa persepsi kualitasberpengaruh positif dan signifikan berhadap terhadap nilai emosional.

Pengujian persamaan 2 dilakukan untuk melihat pengaruh persepsi kualitas dan nilai emosional terhadap niat beli yang dilakukan dengan menggunakan program SPSS. Berdasarkan hasil uji regresi dapat disajikan dalam Tabel 5 berikut:

\section{Tabel 5.}

Hasil Uji Regresi Persepsi Kualitasdan Nilai emosional terhadap Niat Beli

\begin{tabular}{llrrrrrr}
\hline Model & & \multicolumn{7}{c}{ Unstandardized Coefficients } & $\begin{array}{c}\text { Standardized } \\
\text { Coefficients } \\
\text { Beta }\end{array}$ & t & Sig. \\
& & B & Std. Error & Ber & \\
\hline \multirow{3}{*}{1} & (Constant) & 3.323 & 1.204 & & 2.760 & .007 \\
& Persepsi Kualitas & .312 & .077 & .497 & 3.162 & .012 \\
& Nilai Emosional & .350 & .053 & .680 & 6.641 & .000 \\
\hline
\end{tabular}

Sumber: Data diolah, 2018

Persamaan Struktural 2

$$
\begin{aligned}
& \mathrm{Y}_{2}=\beta_{2} \mathrm{X}+\beta_{3} \mathrm{Y}_{1}+\varepsilon_{2} \ldots \ldots \\
& \mathrm{Y}_{2}=0,497 \mathrm{X}+0,680 \mathrm{Y}_{1}+\varepsilon
\end{aligned}
$$

Tabel 5 menunjukkan hasil uji regresi pengaruh persepsi kualitasdan nilai emosionalterhadap niat beli.persepsi kualitasdengan nilai Sig. 0,012 $<0,05$ menunjukkan bahwa persepsi kualitas berpengaruh positif dan signifikan terhadap niat beli. nilai emosional dengan nilai Sig. $0,000<0,05$ menunjukkan bahwa nilai emosional berpengaruh positif dan signifikan terhadap niat beli.

Untuk mengetahui nilai $\mathrm{e}_{1}$ yang menunjukkan jumlah variance variabel nilai emosional yang tidak dijelaskan oleh variabel persepsi kualitas dihitung menggunakan rumus. 
Pei $=\sqrt{1-\mathrm{Ri}^{2}}$

$\mathrm{Pe}_{1}=\sqrt{1-\mathrm{R}_{1}^{2}}=\sqrt{1-0,487^{2}}=0,873$

Nilai variance variabel nilai emosional yang tidak dijelaskan oleh variabel persepsi kualitas sebesar 0,873 berarti terdapat kumpulan variabel eksogen lainnya yang tidak dimasukkan dalam sistem penelitian yang dimungkinkan masih mempengaruhi variabel endogen atau niat beli (Y2).

Sedangkan untuk mengetahui nilai $\mathrm{e}_{2}$ yang menunjukkan variance variabel niat beli yang tidak dijelaskan oleh variabel persepsi kualitas dan nilai emosional, maka dihitung menggunakan rumus.

Pei $=\sqrt{1-\mathrm{Ri}^{2}}$

$\mathrm{Pe}_{2}=\sqrt{1-\mathrm{R}_{2}^{2}}=\sqrt{1-0,478^{2}}=0,879$

Nilai variance variabel niat beli yang tidak dijelaskan oleh variabel persepsi kualitas dan nilai emosional sebesar 0,875 berarti terdapat kumpulan variabel eksogen lainnya tidak dimasukkan dalam penelitian ini yang mungkin masih dapat mempengaruhi variabel endogen atau niat beli (Y2).

Untuk memeriksa validitas model, terdapat indikator untuk melakukan pemeriksaan, yaitu koefisien determinasi total hasilnya sebagai berikut.

$$
\begin{aligned}
\mathrm{R}^{2} \mathrm{~m} & =1-\left(\mathrm{Pe}_{1}\right)^{2}\left(\mathrm{Pe}_{2}\right)^{2} \ldots \ldots \\
& =1-(0,873)^{2}(0,879)^{2} \\
& =0,412
\end{aligned}
$$

Keterangan :

$\mathrm{R}_{\mathrm{m}}^{2} \quad$ : Koefisien determinasi total

$\mathrm{e}_{1}, \mathrm{e}_{2}$ : Nilai kekeliruan taksiran standar

Uji Sobel dirumuskan dengan persamaan berikut: 
Keterangan :

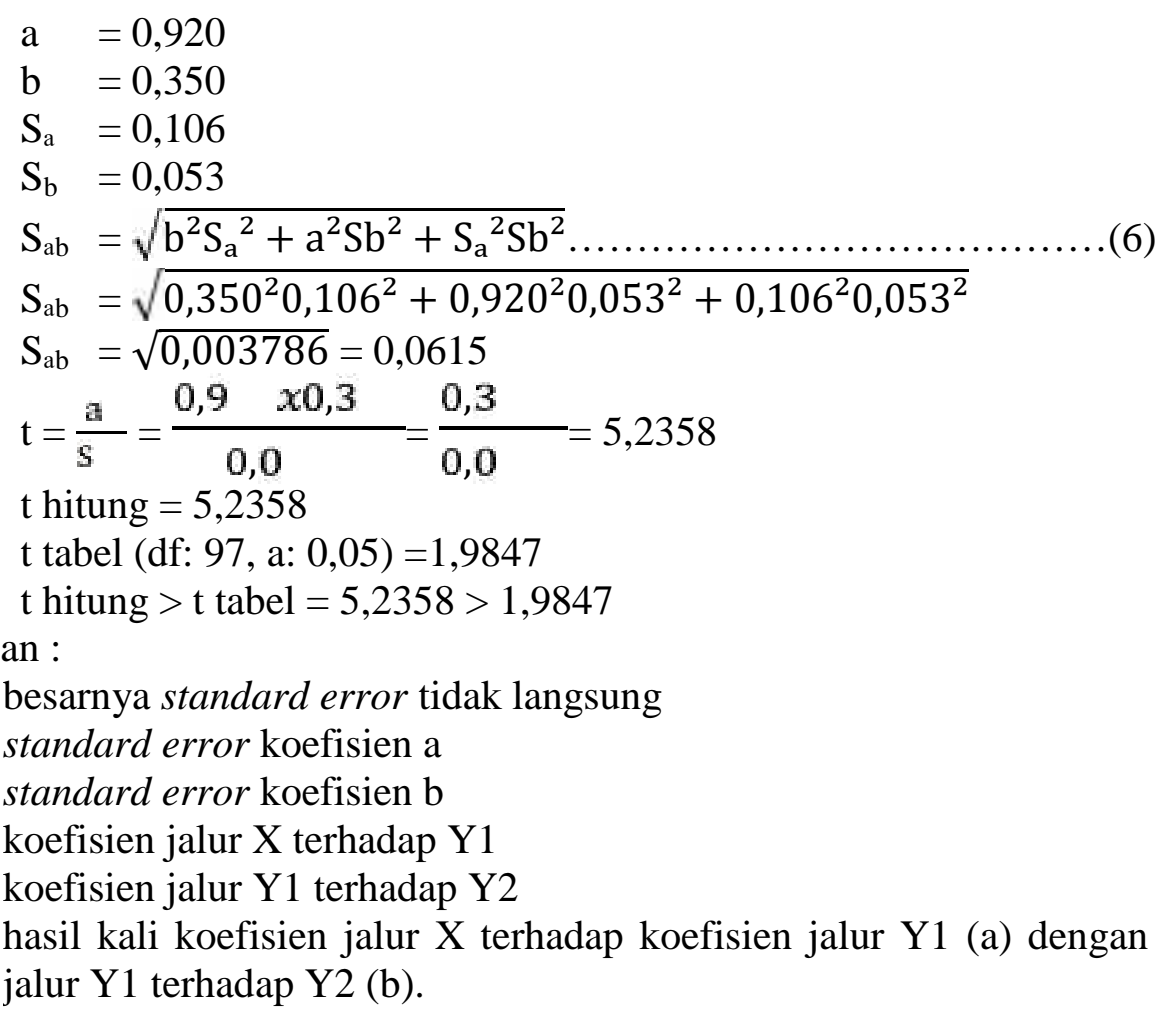

Oleh karena $\mathrm{Z}$ hitung sebesar 5,2358 > 1,9847 artinya nilai emosional (Y1) sebagai variabel mediasi pengaruh tidak langsung persepsi kualitas (X) terhadap niat beli (Y2).

Tabel 6 menjelaskan bahwa variabelpersepsi kualitas (X) berpengaruh signifikan terhadap nilai emosional (Y1), variabel nilai emosional (Y1) berpengaruh signifikan terhadap niat beli (Y2), dan variabel persepsi kualitas (X) berpengaruh signifikan terhadap niat beli (Y2).

Tabel 6.

Ringkasan Koefisien Jalur

\begin{tabular}{llllll}
\hline Regresi & Koef. Regresi Estandar & Standar Error & t hitung & p value & Keterangan \\
\hline $\mathrm{X} \rightarrow \mathrm{Y} 1$ & 0,698 & 0,106 & 9,636 & 0,000 & Signifikan \\
$\mathrm{Y} 1 \quad \rightarrow$ & 0,497 & 0,077 & 6,641 & 0,012 & Signifikan \\
$\mathrm{Y} 2$ & & 0,053 & 3,162 & 0,000 & Signifikan \\
$\mathrm{X} \rightarrow \mathrm{Y} 2$ & 0,680 & & & &
\end{tabular}


Keterangan :

$\mathrm{X}=$ Persepsi Kualitas

$\mathrm{Y} 1=$ Nilai Emosional

$\mathrm{Y} 2=$ Niat Beli

Pengaruh langsung, pengaruh tidak langsung dan pengaruh total antar variabel dalam Tabel 7 berikut:

Tabel 7.

Ringkasan Pengaruh Langsung, Pengaruh Tidak Langsung dan Total Pengaruh Antar Variabel Penelitian

\begin{tabular}{cccc}
\hline \multirow{2}{*}{ Pengaruh Variabel } & $\begin{array}{c}\text { Pengaruh } \\
\text { Langsung }\end{array}$ & $\begin{array}{c}\text { Pengaruh Tidak Langsung } \\
\text { Melalui Mediasi } \\
\left(\boldsymbol{\beta}_{\mathbf{1}} \mathbf{x} \boldsymbol{\beta}_{\mathbf{3}}\right)\end{array}$ & Pengaruh Total \\
\hline $\mathrm{X} \rightarrow \mathrm{Y} 1$ & 0,698 & - & 0,698 \\
$\mathrm{X} \rightarrow \mathrm{Y} 2$ & 0,497 & 0,475 & 0,972 \\
$\mathrm{Y} 1 \rightarrow$ Y2 & 0,680 & - & 0,680 \\
\hline
\end{tabular}

Sumber: Data diolah, 2018

Pada Tabel 7 pengaruh langsung $\mathrm{X}$ terhadap $\mathrm{Y} 1$ adalah 0,698. Tidak terdapat pengaruh tidak langsung sehingga pengaruh totalnya 0,698. Pengaruh langsung $\mathrm{X}$ terhadap $\mathrm{Y} 2$ adalah 0,497 . Pengaruh tidak langsung $\mathrm{X}$ terhadap $\mathrm{Y} 2$ melalui Y1 diperoleh dari 0,698 x 0,680 =0,475. Oleh karena itu, pengaruh total X terhadap Y2 melalui Y1 adalah sebesar 0,497 $+0,475=0,972$ Ini berarti bahwa terdapat pengaruh tidak langsung variabel persepsi kualitas terhadap niat beli melalui nilai emosional.

Berdasarkan hasil penelitian yang diperoleh dalam analisis data dapat diketahui bahwa nilai sig. $\mathrm{t}$ sebesar 0,000 dengan nilai koefisien beta sebesar 0,698. Nilai sig. $\mathrm{t}$ yang memperlihatkan nilai $0,000<0,05$, maka dapat disimpulkan bahwa terdapat pengaruh positif dan signifikan antara persepsi kualitasterhadap nilai emosional. Hasil tersebut memperlihatkan bahwa semakin baik persepsi terhadap kualitas Sepatu Olahraga Lari Nike maka akan 
meningkatkan nilai emosional yang dirasakan pada Sepatu Olahraga Lari Nike. Hasil penelitian ini didukung oleh hasil dari penelitian sebelumnya yang dilakukan oleh Nadya dan Sihombing (2012) dalam hubungan antara pengaruh normatif dan niat beli pada pakaian merek luar negeri menyatakan bahwa terdapat hubungan positif antara variabel persepsi kualitas dan nilai emosional. Hasil penelitian ini juga selaras dengan penelitian yang dilakukan oleh Lee et al. (2008), dan Shah et al. (2012) yang menyatakan bahwa persepsi kualitas memiliki pengaruh positif dan signifikan terhadap nilai emosional.

Berdasarkan hasil penelitian yang diperoleh dalam analisis data dapat diketahui bahwa nilai sig. $\mathrm{t}$ sebesar 0,012 dengan nilai koefisien beta sebesar 0,497. Nilai sig. $\mathrm{t}$ yang memperlihatkan nilai $0,012<0,05$, maka dapat disimpulkan bahwa terdapat pengaruh positif dan signifikan antara pesepsi kualitasterhadap niat beli. Hasil tersebut memperlihatkan bahwa semakin baik persepsi terhadap kualitas Sepatu Olahraga lari Nike maka akan meningkatkan niat untuk membeli Sepatu Olahraga Lari Nike. Hasil dalam penelitian ini didukung oleh hasil dari penelitian sebelumnya yang dilakukan oleh Levy dan Guterman (2012) dan Gatti et al. (2012) yang mengungkapkan persepsi kualitas berpengaruh positif dan signifikan terhadap niat beli. Hasil penelitian ini juga selaras dengan penelitian yang dilakukan oleh Lomboan (2017), Walangitan dkk. (2015) serta Indrayani dan Nurcahya (2014) yang menyatakan bahwa persepsi kualitas memiliki pengaruh positif dan signifikan terhadap niat beli.

Berdasarkan hasil penelitian yang diperoleh dalam analisis data dapat diketahui bahwa nilai sig. $\mathrm{t}$ sebesar 0,000 dengan nilai koefisien beta sebesar 
0,680. Nilai sig. $\mathrm{t}$ yang memperlihatkan nilai $0,000<0,05$, maka dapat disimpulkan bahwa terdapat pengaruh positif dan signifikan antara nilai emosional terhadap niat beli. Hasil tersebut memperlihatkan bahwa semakin baik nilai emosional yang dirasakan pada Sepatu Olahraga Lari Nike maka akan meningkatkan niat untuk membeli Sepatu Olahraga Lari Nike. Hasil dalam penelitian ini didukung oleh hasil dari penelitian sebelumnya yang dilakukan oleh Saidani dkk. (2017) yang mengungkapkan bahwa nilai emosional berpengaruh positif dan signifikan terhadap niat beli. Hasil penelitian ini juga selaras dengan penelitian yang dilakukan oleh Kashi et al. (2013) dan Nadya dan Sihombing (2012) yang menyatakan bahwa nilai emosional memiliki pengaruh positif dan signifikan terhadap niat beli.

Berdasarkan hasil yang diperoleh melalui uji sobel dapat diketahui bahwa pada ujipengaruh tidak langsung, pengaruh persepsi kualitas terhadap niat beli melalui nilai emosional mendapatkan $\mathrm{Z}$ hitung yakni sebesar 5,2358 lebih besar dari t tabel yakni sebesar 1,9847. Hasil tersebut menyatakan bahwa variabel nilai emosional dinilai secara signifikan memediasi pengaruh antara variabel persepsi kualitas terhadap variabel niat beli Sepatu Olahraga Lari Nike. Hasil dalam penelitian ini didukung oleh hasil dari penelitian sebelumnya yang dilakukan oleh Shah et al. (2012) yang menemukan bahwa nilai emosional mampu memediasi secara positif dan signifikan terhadap niat beli. Hasil penelitian ini juga selaras dengan penelitian yang dilakukan Nadya dan Sihombing (2012). Dalam penelitian yang dilakukan Latter et al. (2010) mengatakan bahwa nilai emosional mampu 
berperan sebagai variabel mediasi antara variabel endogen dengan variabel eksogen.

Implikasi dari penelitian ini mencakup dua hal yaitu, implikasi teoritis dan implikasi praktis yang menekankan pada manfaat nyata dari hasil penelitian ini untuk meningkatkan niat beli pada produk sepatu merek Nike. Perusahaan sebaiknya mempertahankan nilai emosionalyang baik melalui persepsi akan kualitas yang baik sehingga produk sepatu merek Nike menimbulkan niat beli yang tinggi. Beberapa implikasi hasil penelitian ini adalah sebagai berikut.

Faktor yang berhubungan dengan niat beli dalam peneltian ini adalah persepsi kualitas dan nilai emosional. Implikasi teoritis yang berkaitan dengan niat beli secara konsisten memperkuat teori sebelumnya bahwa persepsi kualitas dan nilai emosional mempengaruhi timbulnya niat untuk membeli. Selain itu, variabel nilai emosional mampu menjadi pemediasi persepsi kualitas dengan niat beli. Semakin baik persepsi kualitas yang dimiliki produk Sepatu Olahraga Lari Nike maka akan dapat meningkatkan nilai emosional yang baik, dan nilai emosional tersebut memiliki peranan penting dalam mempengaruhi niat beli Sepatu Olahraga lari Nike. Hal ini mendukung penelitian yang telah diungkapkan pada hipotesis penelitian, sehingga dapat disimpulkan bahwa penelitian ini mendukung serta memperjelas hubungan antara variabel nilai emosional, persepsi kualitas, dan niat beli.

Hasil dari penyebaran kuesioner secara spesifik yang ditunjukkan dalam pernyataan responden tentang persepsi kualitas, nilai emosioanl dan niat beli bahwa mereka rata-rata setuju pada pernyataan mengenai persepsi kualitas, nilai 
emsoional dan niat beli, maka dengan begitu dapat disimpulkan bahwa pernyataan tersebut dapat merefleksikan perilaku pembelian konsumen yang berarti bahwa responden memiliki niat beli.

Patut disadari bahwa terdapat beberapa keterbatasan dari penelitian ini adalah penelitian ini hanya dilakukan dalam titik waktu tertentu, sedangkan lingkungan setiap saat dapat berubah, yang menyebabkan penelitian ini penting untuk dilakukan kembali pada masa yang mendatang.Kurangnya variabel, di mana masih ada variabel-variabel lain yang dapat mempengaruhi niat beli seperti, brand image, citra toko, harga, dan promosi penjualan.Penelitian ini belum spesifik, karena dilakukan pada keseluruhan tipe Sepatu Olahraga Lari Nike, sedangkan Sepatu Olahraga Nike memiliki banyak tipe-tipe sepatu olahraga.

\section{SIMPULAN DAN SARAN}

Simpulan dari penelitian ini serta pembahasan mengenai pengaruh masingmasing variabel yang telah dipaparkan, maka dapat ditarik kesimpulan sebagai berikut: variabel persepsi kualitas berpengaruh positif dan signifikan terhadap nilai emosional. Hal tersebut menunjukkan semakin baik persepsi akan kualitas pada Sepatu Olahraga Lari Nike maka akan meningkatkan nilai emosional yang dirasakan dari produk Sepatu Olahraga Lari Nike di Kota Denpasar. Persepsi Kualitas berpengaruh positif dan signifikan terhadap niat beli. Hal tersebut menunjukkan semakin baik persepsi akan kualitas pada Sepatu Olahraga Lari Nike maka akan meningkatkan niat beli produk Sepatu Olahraga Lari Nike di Kota Denpasar. Nilai emosional berpengaruh positif dan signifikan terhadap niat beli. Hal tersebut menunjukkan semakin baik nilai emosional pada Sepatu 
Olahraga Lari Nike maka akan meningkatkan niat beli produk Sepatu Olahraga Lari Nike di Kota Denpasar. Nilai emosional mampu memediasi pengaruh persepsi kualitas terhadap niat beli. Hal tersebut menunjukkan bahwa nilai emosional memediasi pengaruh persepsi kualitas terhadap niat beli secara parsial. Dengan kata lain, nilai emosional memperkuat pengaruh persepsi kualitas ke niat beli.

Saran yang dapat diajukan berdasarkan hasil penelitian ini adalah pihak Nike perlu memperhatikan keandalan produk agar performa produk yang ditawarkan mampu meningkatkan niat untuk membeli pada produk Sepatu Olahraga Lari Nike. Pihak produsen Nike diharapkan dapat mempetahankan persepsi kualitas produk yang baik untuk para konsumen dan dapat meningkatkan serta mempertahankan nilai emosional yang dirasakan pada produk Nike. Nilai emosional disini mampu menarik minat konsumen untuk membeli suatu produk, sehingga dapat menggungguli minat beli dari produk sepatu olahraga lari para pesaing Sepatu Olahraga Lari Nike. Bagi peneliti selanjutnya, diharapkan untuk melakukan penelitian secara spesifik pada tipe Sepatu Olahraga Lari Nike. Dalam penelitian ini di masa mendatang juga perlu untuk menggunakan variabelvariabelyang lain seperti brand image, citra toko, harga, dan promosi penjualan, sehingga dapat memperkaya informasi yang diperoleh.

\section{REFERENSI}

Alissa, Safiera. (2017). ini sneakers yang paling dicari di google sepanjang 2017. https://wolipop.detik.com/read/2017/12/14/173337/3770058/233/inisneakers-yang-paling-banyak-dicari-di-google-sepanjang-2017. Diakses 12 Febuari 2018. 
Anggi, C. dan Elleywati J., (2015). Pengaruh Etnosentrisme Konsumen Pada Niat Beli Produk Notebook : Uji Mediasi Variabel Persepsi Kualitas. Jurnal Universitas Atma Jaya, 1 (1), hal. 1-14.

Annafik, A. F., dan M. Rahardjo. (2012). Analisis Pengaruh Kualitas Produk, Harga dan Daya Tarik Iklan Terhadap Niat Membeli Sepeda Motor Yamaha (Studi Kasus Pada Konsumen Yamaha Ss Cabang Kedungmundu Semarang). Journal Of Management. 1 (2), hal. 274-281.

Babin, B.J. and Harris, E.G. (2011). Consumen behavior 2. USA: South-Western Cengange Lerarning.

Barber, Nelson., Pei-Jou, Kuo., Malissa, Bishop. and Raymond, Goodman Jr. (2012). Measuring Psychographics to Assess Purchase Intetion and Willness to Pay. Journal Consumer Marketing. 29 (24), pp. 280-292.

Dewi, Pratiwi. (2017). Nike Siapkan Jersey Baru Untuk Timnas di Asian Games. http://wartakota.tribunnews.com/2017/11/18/Nike-siapkan-jersey-baruuntuk-timnas-indonesia-di-asian-games. Diakses 22 Febuari 2018.

Durianto, D., Sugiarto, dan Sitinjak, T. (2011). Strategi Menaklukkan Pasar Melalui. Riset Ekuitas dan Perilaku Merek. Jakarta: PT. Gramedia.

Filz, Jeen., Blomme, Robert J., Van Rheede, Arjan. (2016). The Marketing Value Of Csr Initiatives And Potential Brand Equity, Taste Perception, And Emotional Value. Advances in Hospitality and Leisure Journal. 1 (12), pp. 99-117.

Ghozali, Imam. (2011). Aplikasi Analisis Multivariate Dengan Program SPSS. Semarang: Universitas Diponegoro.

Hawkins, Delberts and David Mothersbaugh. (2010). Consumer Behavior: Building Marketing Strategy, $11^{\text {th }}$ ed. New York: McGraw-Hill Companies, Inc.

Hertanto, Christian Yohanes. (2013). Pengaruh Brand Awerness, Perceived Quality, Brand Association, dan Brand Loyalty Terhadap Brand Attitude Melalui Efektifitas Iklan Shampo L'oreal Di Surabaya. Jurnal Ilmiah Mahasiswa Manajemen (JUMMA), 2 (4), hal.1-5.

Indrayani, Linda. dan Nurcahya I.NY. (2014). Peran Persepsi Kualitas Produk Dalam Memediasi Pengaruh Gaya Hidup Terhadap Niat Beli Handphone Samsung Galaxy Di Kota Denpasar. E-Jurnal Manajemen Unud. 3 (4), hal. 885-897.

Ismayanti, Arie N.M. dan Santika, I.W. (2017). Pengaruh Celebrity Endorser, Brand Image, Kualitas Produk Terhadap Niat Beli Sepatu Olahraga Nike Di Kota Denpasar, E-Jurnal Manajemen Unud. 6 (10), hal. 5720-5747. 
Kashi, M.N., Boojari H., and Rasoulian, M. (2013). Perceived Quality and Emotional Value Among Iranian Consumers' Strategies, EuropeanOnline Journal of Natural and Social Sciences. 2 (3), pp. 2868-2877.

Kumar, Archana. and Kim Youn-Kyung. (2008). Indian consumers' purchase behavior toward US versus local brands.International Journal of Retail \&Distribution Management. 37 (6), pp. 510-526.

Kotler, Philip. dan Gary, Amstrong., (2012). Prinsip-prinsip Marketing, Jakarta: Salemba Empat.

Kotler, Philip. and Kevin, L. Keller. (2012). Marketing management, $14^{\text {th }}$ ed. USA: Pearson Education, Inc.

Laluyan, N.D., Pengemanan, S.S. dan Worang, F.G. (2017). Pengaruh Periklanan, Persepsi Kulitas Dan Kesadaran Merek Pada Niat Beli Konsumen (Studi Kasus: Sepatu Olahraga Adidas). Jurnal Emba, 5 (2), hal. 267-278.

Latter, Chelsey, Ian, Phau. and Chris, Marchegiani. (2017).The Roles of Consumers Need for Uniquenessand Status Consumption in Haute Couture Luxury Brands. Journal of Global Fashion Marketing. 1 (4), pp. 206-214.

Lee, M.Y., Kim, Y.K., Pelton, L., Knight, D. and Forney, J. (2008). Factors Affecting Mexican College Students' Purchase Intention Toward A Us Apparel Brand. Journal Of Fashion Marketing And Management. 12(3), pp. 294-307.

Levy, Shalom. and Hanna, Gendel-Gunterman. (2012). Does Advertising Matter To Store Brand Purchase Intention? A Conceptual Framework.Journal Of Product \& Brand Management. 21 (2), pp. 89-97.

Lobo, Antonio. and Chen, Jue. (2012). Marketing Of Organic Food In Urban China: An Analysis of Consumer Lifestyle Segment. Journal of Internasional Marketing And Exporting. 17 (1), pp. 14-26.

Lomboan, Leonika K. (2017). Analysis The Influence Of Perceived Quality, Perceived Price And Perceived Value On Consumer Purchase Intention In Traditional Fabrics. Jurnal Berkala lmiah Efisiensi 17 (1), pp. 100-112.

Nadya, S., dan Sihombing, S.O. (2012). Hubungan Antara Pengaruh Normative dan Niat Beli Pakaian Merek Luar Negeri: Kesadaran Merek, Kualitas, dan Nilai Emosi Sebagai Variabel Mediasi. Jurnal Cbam, 1 (1), hal. 961-975.

Putri, Devina A. dan Semuel Hatane., (2016). Pengaruh Store Atmosphere terhadap Purchase Intention dengan Perceived Quality sebagai Variabel Intervening pada Victoria's Secret Surabaya. Jurnal Universitas Kristen Petra, 1 (1), hal. 1-21. 
Riduwan. dan Engkos, Achmad Kuncoro. (2011). Cara Menggunakan dan Memakai Path Analysis (analisis jalur).Bandung : Alfabeta.

Sadat, Andi M. 2009. Brand Belief : Strategi Membangun Merek Berbasis Keyakinan. Jakarta: Salemba Empat.

Saidani, B., Mustahid, M.S. dan Haro, A. (2017). The Influence Of Perceived Quality, Brand Image, And Emotional Value Towards Purchase Intention Of Consina Backpack. Jurnal Riset Manajemen Sains Indonesia (JRMSI). 8 (19), pp. 1-19.

Schiffman, Leon G., Lesle, Lazar Kanuk. and Joseph, Wisenblit. (2010), Consumer Behavior Global Edition . $10^{\text {th }}$ ed. United Star Of America: Prentince Hall.

Sekaran, Uma. (2014). Metodologi Penelitian untuk Bisnis (Research Methods for Business). (Buku 1) $4^{\text {th }}$ ed. Jakarta: Salemba Empat.

Setyawan, Budi. (2010). Pengaruh Perceived Quality, Perceived Sacrifice, Perceived Value, Satifaction Pada Behavioural Intentions. E-jurnal Manajemen UNS. 1 (32), pp. 23-31.

Shah, Syed Iqbal., Akmal, Shahzad., Tanvir, Ahmed. and Irfan, Ahmed.(2012)Factors Affecting Pakistan's University Students' Purchase Intention Towards Foreign Apparel Brands. Journal Management. 17 (1), pp. 1-14.

Simamora, Bilson. (2002). Aura Merek. Jakarta: PT Gramedia Pustaka Utama.

Simamora, Bilson. (2008). Panduan Riset Perilaku Konsumen. Edisi 1. Jakarta: PT Gramedia Pustaka Utama.

Sugiyono. (2017). Metode Penelitian Bisnis.Bandung : CV Alfabeta.

Tjiptono, Fandy. (2012). Pemasaran Jasa, Malang: Bayumedia Publishing.

Top Brand, (2017), Top Brand Awards Sepatu Olahraga, www.TopbrandAward.Com, Diakses Pada 20 Oktober 2017.

Walangitan, Arindah., Pangemanan, Sifrid S. and Rumokoy, Farlane S. (2015). Analysing The Impact Of Brand Equity On Consumer Purchase Intention Of Etude House Cosmetic Product In Manado. Jurnal EMBA. 3 (2), pp. 758-766.

Wen, Ling-yu. and Li, Sang-Hui. (2013). A Study On The Relationship Amidst Health Consciousness, Ecological Affect, And Purchase Intention Of Green Production. 5(4), pp. 124-137. 
Wijaya, Andrew., Samuel Hatane. dan Japrianto, Edwin. (2013). Analisa Pengaruh Perceived Quality Terhadap Perceived Value Konsumen Pengguna Internet MobileXl di Surabaya. Jurnal Manajemen Pemasaran Petra. 1 (1), hal 1-12.

Xu, F., Li, Y. and Zhou, J. (2015). Brand Awareness for Entrepreneurial Hotel Chains: Perceived Quality and Brand Loyalty. Brand Awareness For Enterpreneurial Hotel Chains. 19 (3), pp. 763-771.

Yamin, Regina. (2013). Persepsi Nilai, Persepsi Kualitas, dan Citra Terhadap Kepuasan Konsumen Pada Pt. Astra International Daihatsu Di Manado. Jurnal EMBA. 1 (3), hal. 1231-1240.

Zuhra, Wan Ulfa Nur. (2017). Cetakan Wafel dan kisah kelahiran Sepatu Nike. Https://tirto.id/cetakan-wafel-dan-kisah-kelahiran-sepatu-Nikect2d.Diakses 20 Febuari 2018. 